\title{
Satisfaction with life and its determinants in the group of patients with ulcerative colitis
}

Satysfakcja z życia i jej determinanty w grupie chorych z wrzodziejącym zapaleniem jelita grubego

\section{Maria Kózka', Wioletta Skowron²}

\begin{abstract}
1Institute of Nursing and Midwifery, Faculty of Health Sciences, Jagiellonian University Medical College/ Instytut Pielęgniarstwa i Położnictwa, Wydział Nauk o Zdrowiu, Uniwersytet Jagielloński Collegium Medium Kraków ${ }^{2}$ Faculty of Health Sciences, Polonia University in Czestochowa/ Wydział Nauk o Zdrowiu, Akademia Polonijna w Częstochowie
\end{abstract}

ORCID:

Maria Kózka: 0000-0002-5165-6929 Wioletta Skowron: 0000-0003-0453-0773

CORRESPONDING AUTHOR/AUTOR DO KORESPONDENCJ:

Wioletta Skowron

ul. Olchowa 9, 42-290 Blachownia e-mail: wioletta-skowron@wp.pl

\section{STRESZCZENIE}

Słowa kluczowe:

ABSTRACT
SAIYSFAKCJAZZZYCIA IJEJ DEIERMINANIY W GRUPIE CHORYCH Z WRZODZIEJACYM ZAPALENIEM JELITA GRUBECO Wprowadzenie. Satysfakcja z życia oraz jej determinanty to komponenty dobrostanu człowieka, które jednostka ocenia w obszarze jakości życia, na podstawie przyjętych własnych kryteriów. Szczególne zainteresowanie wzbudza poznanie tych czynników u osób, które zmagają się z chorobami przewlekłymi, takimi jak wrzodziejące zapalenie jelita grubego.

Cel pracy. Celem pracy było poznanie poziomu satysfakcji z życia oraz jej determinantów takich jak: akceptacja choroby, uogólniona własna skuteczność pacjentów z wrzodziejącym zapaleniem jelita grubego.

Materiał i metody. Badaniem prospektywnym objęto grupę 102 pacjentów z rozpoznanym wrzodziejącym zapaleniem jelita grubego, u których zbadano poziom satysfakcji z życia oraz poziom akceptacji choroby i uogólnioną własną skuteczność. Do analizy danych zastosowano statystykę opisową, testy parametryczne i nieparametryczne. Analizy korelacyjne dla zmiennych wyrażonych w skalach porządkowych dokonano za pomocą korelacji r-Pearsona. Przyjęto istotność na poziomie $p<0,05$.

Wyniki. Poziom satysfakcji z życia, akceptacja choroby i uogólniona własna skuteczność u osób badanych były obniżone. Poziom satysfakcji z życia był zależny od poziomu własnej skuteczności i akceptacji choroby. Poziom satysfakcji z życia badanych korelował z uogólnioną własną skutecznością i akceptacją choroby. Wyższy poziom satysfakcji z życia uzyskali badani z wyższym poziomem akceptacji choroby i przekonani o skutecznym radzeniu sobie z sytuacjami trudnymi. Mężczyźni prezentowali lepsze wyniki niż kobiety. Wnioski. Satysfakcja z życia i jej determinanty u pacjentów z wrzodziejącym zapaleniem jelita grubego były obniżone. Badani z wykształceniem zawodowym osiągali niższe wyniki niż osoby z wykształceniem średnim i wyższym. Kobiety prezentowały niższe poziomy zmiennych niż mężczyźni. Poziom satysfakcji był zależny od akceptacji choroby i od uogólnionej własnej skuteczności.

poziom satysfakcji, determinanty satysfakcji zżycia

\section{SATISFACIION WITH LIFE AND IIS DETERMINANIS IN THE GROUP OF PATIENIS WITH ULCERATIVE COLITIS}

Introduction. Satisfaction with life and its determinants are components of human well-being, which the individual assesses in the area of quality of life, based on the own adopted criteria. Of particular interest is the recognition of these factors in people who are struggling with chronic diseases such as ulcerative colitis.

Aim. The aim of the work was to get to know the level of life satisfaction as well as its determinants such as acceptance of the disease and generalized self-efficacy of patients with ulcerative colitis.

Material and methods. The prospective study included 102 patients with diagnosed ulcerative colitis, who were tested for the level of life satisfaction and the level of disease acceptance and generalized self-efficacy. Descriptive statistics, parametric and nonparametric tests were used for data analysis. Correlation analyzes for variables expressed in ordinal scales were made using $r$-Pearson correlation. Significance was assumed at the level of $p<0.05$.

Results. The level of life satisfaction, acceptance of the disease and generalized self-efficacy in the subjects were reduced. The level of life satisfaction was dependent on the level of self-efficacy and acceptance of the disease. The level of life satisfaction of the respondents correlated with the generalized own effectiveness and acceptance of the disease. A higher level of life satisfaction was obtained by respondents with a higher level of disease acceptance and convinced of effective coping with difficult situations. Men presented better results than women.

Conclusions. Satisfaction with life and its determinants in patients with ulcerative colitis were reduced. The respondents with vocational education achieved lower results than those with secondary and higher education. Women presented lower variable levels than men. The level of satisfaction was dependent on the acceptance of the disease and on the generalized own effectiveness. 


\section{INTRODUCTION}

Ulcerative colitis is a chronic disease whose onset is usually sudden. The chronic nature of the disease affects a patient with a change in the perception of the world. It often generates the re-evaluation of life and the verification of previous priorities [1]. Life satisfaction is defined as a cognitive and emotional assessment of one's own life [2], or as subjective feeling of well-being and mental comfort [2]. Quite often life satisfaction is associated with contentment, happiness, well-being or quality of life [3]. Undoubtedly, positive and negative situations affect people's satisfaction with life. It may increase or decrease their reception and this fact usually leads to an ad hoc result. In contrast, traumatic situations may have a long-term effect on life satisfaction [4].

An important element determining life satisfaction is the acceptance of the disease and personal resources that facilitate the adoption of changes. The current research shows that patients who accept the disease experience fewer negative emotions. Moreover, the acceptance of the disease increases faith in the sense of the treatment [5]. Disease acceptance is a long-term process of recovering the patient's mental balance and reducing emotional discomfort. It is also a result of coping with the disease and its consequences, such as: pain, diarrhoea, malaise $[6,7,8,9]$.

Patients' behaviour in the face of disease and their influence on their own health constitute an element of reflection on self-efficacy, which is one of the fundamental mechanisms of human behaviour's self-regulation in terms of cognitive and motivational functioning. Faith in own capabilities determines how we think, feel, behave and it also motivates us to act. Therefore, it is our cognitive and efficient activity that determine the conviction of own efficacy which means faith in one's own organisational skills, helping to implement the activities necessary to overcome encountered obstacles $[10,11,12]$.

Symptoms of the disease, stress and coping with it, acceptance of the disease, the feeling of self-efficacy and many other determinants affect the patient's life satisfaction [2].

Ulcerative colitis is a very difficult experience for the patients, as it significantly changes their lifestyle, functioning at home and on a professional or social level [13].

\section{AIM}

The aim of the work was to learn the level of life satisfaction as well as its selected determinants such as: acceptance of the disease and generalised self-efficacy in patients with ulcerative colitis.

\section{MATERIALS AND METHODS}

The level of life satisfaction and its determinants were researched in 102 patients with confirmed clinical diagnosis of ulcerative colitis, treated conservatively in the Regional Specialist Hospital in Czestochowa at the Department of Gastroenterology and at the Gastrological Clinic.
The selection of the group was intentional. The patients were selected on the basis of confirmed diagnosis of the disease and time of illness of at least a year. The consents of the patients and of the Bioethics Committee of The Regional Medical Chamber in Czestochowa (Komisja Bioetycznej Okręgowej Izby Lekarskiej in Czestochowa (No. K.B.Cz.-9/2012) were obtained.

Over half of the sample group (52\%) were women. The age of the researched patients ranged from 18 to 79 years of age, and the average age was 41.02 . As many as $85 \%$ of the patients had higher and secondary education, $73 \%$ were professionally active. In the sample group, most of the patients $(71 \%)$ lived in the city. The patients had been suffering from the disease for 1-27 years.

To collect the data, the diagnostic survey method was used, with the standard research tools: the Satisfaction with Life Scale, Acceptance of Illness Scale, General Self-Efficacy Scale and the author's questionnaire. The subjective sense of satisfaction with life was made using the Satisfaction with Life Scale (SWLS), which consists of 5 statements. In each question, from 1 to 7 points could be obtained. The results are summed up and their range is from 5 to 35 points. The higher the score, the greater the sense of life satisfaction [14].

The disease acceptance was evaluated with the Acceptance of Illness Scale (AIS) which contains 8 statements describing negative consequences of bad state of health. In each statement, the patient determines his/her current state on a 5-point scale (from 1 to 5 ). The results are summed up and they range from 8 to 40 . Low result means the lack of acceptance and adaptation to the disease, and strong sense of psychological discomfort. The high score indicates the acceptance of one's own medical condition which is manifested by the lack of negative emotions associated with the disease [14]. Generalised self-efficacy was assessed using the Generalised Self-Efficacy Scale (GSES), which contains 10 statements and is used to assess the effectiveness of one's dealing with difficult situations and obstacles. A researched patient marks the answers by choosing four variants. The results are obtained by adding points, ranging from 10 to 40 . The higher the score, the greater the sense of self-efficacy [14].

The author's questionnaire contained 12 questions regarding sociodemographic data, professional, social and family functioning of the patients.

For the analysis of data, descriptive statistics and parametric and non-parametric tests were used, depending on the type of scale and the nature of the distribution of variables. Correlation analyses for variables expressed in ordinal scales were made using r-Pearson correlation. The results were assumed to be statistically significant at the significance level of $\mathrm{p}<0.05$.

\section{RESULTS}

The analysis of the obtained data showed that the studied group is characterised by an average level (21.14) of life satisfaction, with the standard deviation -6.05 . The education of the respondents influenced the level of life satisfaction. Lower level of satisfaction with life was 
presented by the patients with vocational education, and the highest - by patients with higher education.

Women achieved a slightly lower level of life satisfaction (20.4) than men (21.9). Statistical analysis did not show dependence of life satisfaction on the age and duration of the disease. The average level of disease acceptance obtained in the study was 28.7 with a standard deviation of 8.4 and was indicative of the average acceptance of the disease. A significant group of researched patients (74\%) showed a high level of disease acceptance, obtaining an average of 32.69 and a low level of acceptance was obtained by $26 \%$ of patients with an average of 17.63 .

The highest percentage of respondents with the lowest disease acceptance occurred in the group of people with vocational education, while in the group of people with secondary education the level of disease acceptance was the highest. Women obtained a slightly lower level of disease acceptance (27.2) than man (30.3). The analysis of the dependence of the patient's disease acceptance level showed a slight decrease in the acceptance of the disease with age and with the increase in the duration of ulcerative colitis.

The assessment of the generalised self-efficacy showed its average level -30.48 , with a standard deviation of 5.25 . These results may confirm reduced generalised self-efficacy among the researched patients. Analysis of the generalised self-efficacy depending on the level of education showed that the highest percentage of respondents with the lowest generalised self-efficacy occurred in the group with vocational education, while the highest percentage of respondents with a high level of generalised self-efficacy occurred in the group with higher education.

Women obtained a slightly lower level of generalised self-efficacy (28.9) than men (32.2).

Analysis of high and low generalised efficacy depending on the age and duration of the disease showed that the respondents with a lower average age presented high generalised self-efficacy. However, subjects with longer time of illness presented a slight decrease in general self-efficacy (Table 1.). A weak negative relationship was found between generalised self-efficacy and duration of disease $(R=-0.20 ; p=0.04)$.

Tab. 1. Level of generalised self-efficacy in relation to the time of disease in the sample group

\begin{tabular}{|l|c|c|c|c|}
\hline $\begin{array}{c}\text { Number of } \\
\text { researched } \\
\text { patients }\end{array}$ & $\begin{array}{c}\text { Level of } \\
\text { generalised } \\
\text { self-efficacy }\end{array}$ & $\begin{array}{c}\text { Average + SD } \\
\text { of the level of } \\
\text { generalised } \\
\text { self-efficacy }\end{array}$ & $\begin{array}{c}\text { Average } \\
\text { age + SD }\end{array}$ & $\begin{array}{c}\text { Average } \\
\text { duration } \\
\text { of disease } \\
\text { + SD }\end{array}$ \\
\hline 16 & Low & $21.44+2.78$ & $51.5+16.68$ & $10.62+7.49$ \\
\hline 86 & High & $32.16+3.64$ & $39.07+13.31$ & $6.44+5.57$ \\
\hline
\end{tabular}

SD - standard deviation

There was no correlation between life satisfaction and duration of the disease. The analysis of the dependence of the disease acceptance and the duration of ulcerative colitis revealed a slight decrease in acceptance as the duration of the disease increased. The correlation of Spearman's rank order between variables did not show any correlation $(\mathrm{R}=-0.18 ; \mathrm{p}=0.07)$.
Examining the correlations between variables, the effect of disease acceptance in the study group was found on: life satisfaction $(\mathrm{R}=0.42 ; \mathrm{p}<0.001)$ and generalised self-efficacy $(\mathrm{R}=0.37 ; \mathrm{p}<0.001)$. The mean correlation between life satisfaction and generalised self-efficacy $(R=0.52$; $\mathrm{p}<0.001$ ) was also observed.

\section{DISCUSSION}

Ulcerative colitis affects every area of life and psychosocial functioning of patients. Analysis of the examined variables, i.e. life satisfaction, disease acceptance and generalised self-efficacy, confirmed these conclusions. An important element of health is well-being, which consists of: the level of life satisfaction, positive emotions and lack of negative feelings [15]. The subjective assessment of life satisfaction is a comparison of one's own situation with the standards set by oneself and consequently, a sense of self-satisfaction [16]. The higher the satisfaction with life, the lower the feeling of stress and the better control of negative feelings.

The result of satisfaction with life of the researched patients fluctuated within 6 stens (21.14 points) and confirmed its average level. Women obtained a slightly lower results (20.4 points) than men (21.9 points). A higher level of life satisfaction occurred in the group of patients with higher education, the lowest level of satisfaction was obtained by the group with vocational education. No studies have been found in the literature on the life satisfaction of patients with ulcerative colitis. The results of own research were compared with life satisfaction studies in the group of patients with other chronic diseases.

H.I. Siudalska et al., in the study of patients operated on due to congenital heart defects, achieved the result of life satisfaction within 5 stens [17]. E. Kupcewicz, M. Wojtkowska obtained a score of 6 stens in the study of patients with discopathy [18]. On the other hand, people with intestinal fistula, in the studies carried out by D. Bazalinski et al., obtained a result within 4-5 stens [19]. The same result was obtained by J. Glinska et al. [20]. In other studies, K. Budyn, A Weiss, concentrating on the elderly patients, the life satisfaction score fluctuated around 5 stens [21], and women in the geriatric age obtained the result of 6 stens in the study by V. Jachimowicz, T. Kostka [22]. In the present research, similar life satisfaction results were obtained in comparison with the studies of other authors. The lowest level of life satisfaction was observed in the group of patients with intestinal fistula.

K. Czubalski, B.J. Felton and T.A. Revenson, in their studies showed that a higher level of acceptance of the disease indicates better adaptation to the disease and less psychological discomfort [23.24]. Other authors $[25,26,27,28]$ confirm the above thesis emphasising the less negative emotions of patients. According to C.A. Siegel, people with a higher level of disease acceptance show greater optimism, trust in the therapeutic team and treatment methods, what leads to active participation of the patient in the therapeutic process [29]. 
In our own studies, the average disease acceptance score equalled 28.7. Women obtained a lower average score (27.2 points) in comparison with men (30.3 points). A higher level of acceptance of the disease was obtained by subjects with secondary education. The results obtained cannot be referred to the results of other authors, because no studies have been conducted so far in patients with ulcerative colitis. The results of the present research were compared with the results of authors conducting research in other chronic diseases. In the group of patients with diabetes, the average acceptance results obtained by K. Kurowska and B. Lach were 25.16 points [30], and by K. Kurpas et al. - 29 points [31]. In contrast, A. Marzec et al., in the group of patients undergoing haemodialysis, achieved an average score of 22.10 points [32]. Patients with Graves' disease in a study conducted by M.A. Basinska et al. obtained an average score of 28.48 points [33]. In another study M.A. Basinska and A. Kasprzak obtained an average disease acceptance score of 27.46 points in patients with psoriasis [34]. The group of women treated for pathological changes in the cervix reached an average acceptance score of 28.76 points in the study of M. Kazmierczak et al. [35].

Both in our own and presented studies of other authors, the average disease acceptance score was comparable, though slightly lower than in haemodialyzed patients.

The sense of self-efficacy is an important determinant of the psychosocial functioning of a person responsible for motivation, that is, readiness for and undertaking pro-health activities [36, 37].

The study group obtained an average score of generalized self-efficacy of 30.48 points. Women obtained a lower result (28.9 points) than the surveyed men $(32.2$ points). The highest level of generalized self-efficacy occurred among patients with higher education (43\%), and the lowest with vocational education (16\%). Patients diagnosed with multiple sclerosis scored an average of 29.5 points [38], with ischemic heart disease after coronary artery bypass surgery - 30.7 points [39], women diagnosed with endometriosis scored 30.0 points [40]. The presented studies showed a comparable level of generalized self-efficacy with their own results.

A connection between the sense of generalized self-efficacy of the researched patients and the acceptance of the disease and satisfaction with life was demonstrated.

Evaluation of the components of the quality of life of patients with ulcerative colitis certainly facilitates communication in the therapeutic team, allowing the patient to receive holistic care, the expected effect of which should be to improve the course of treatment and maintain the remission period of the disease for as long as possible. In practice, usually, the overall assessment of the life quality in chronically ill patients is not made. At most, it is limited to a few questions about their well-being. The routine, professional assessment of the patients' quality of life affects the choice and effectiveness of the procedure, contributes to motivating the patient to self-control and compliance with medical recommendations. Taking this into account, it should be emphasised that a professional assessment of the health condition of a patient with a chronic illness is of great importance in the optimisation of personalised care.

\section{CONCLUSIONS}

1. Life satisfaction, disease acceptance and general self-efficacy in the researched patients with ulcerative colitis were lowered.

2. The patients with vocational education achieved lower results of the tested variables than the patients with higher and secondary education.

3. Women presented lower levels of tested variables than men.

4. The level of life satisfaction was dependent on the level of the disease acceptance and own self-efficacy.

5. The level of life satisfaction of the researched patients correlated with the general self-efficacy and the acceptance of the disease. A higher level of life satisfaction was achieved by the group of patients with higher acceptance level and conviction of effective coping with difficulties and obstacles.

6. The level of generalised self-efficacy of the sample group correlated with the disease acceptance, life satisfaction and gender. A higher level of general self-efficacy was obtained by the patients with higher level of disease acceptance and achieving better life satisfaction. Men presented better results than women. 


\section{Satysfakcja z życia i jej determinanty w grupie chorych z wrzodziejącym zapaleniem jelita grubego}

\section{WPROWADZENIE}

Wrzodziejące zapalenie jelita grubego jest chorobą przewlekłą, której początek zwykle jest nagły. Przewlekły charakter choroby wpływa u osób chorych na zmianę postrzegania świata, dość często wymaga przewartościowania życia i zmianę dotychczasowych priorytetów [1].

Satysfakcja z życia definiowana jest jako poznawcza, emocjonalna ocena własnego życia [2], czy też jako subiektywne odczuwanie dobrego samopoczucia i komfortu psychicznego [2]. Dość często satysfakcję z życia utożsamia się z zadowoleniem, szczęściem, dobrostanem, czy jakością życia [3]. Na zadowolenie z życia człowieka wpływają niewątpliwie pozytywne i negatywne sytuacje. Satysfakcja z życia może zwiększyć lub zmniejszyć ich odbiór, fakt ten daje zwykle rezultat doraźny. Natomiast sytuacje traumatyczne mogą mieć długotrwały wpływ na satysfakcję z życia [4].

Ważnym elementem determinującym satysfakcję z życia jest akceptacja choroby oraz zasoby osobiste, które ułatwiają przystawanie się do zmian. $Z$ dotychczas przeprowadzonych badań wynika, że osoby, które zaakceptowały chorobę przestrzegają zaleceń, doświadczają mniej negatywnych emocji. Ponadto akceptacja choroby zwiększa wiarę w sens podjętego leczenia [5]. Akceptacja choroby jest procesem długotrwałym polegającym na odzyskaniu przez chorego równowagi psychicznej i zmniejszeniu dyskomfortu emocjonalnego, jest zarazem wynikiem radzenia sobie $\mathrm{z}$ chorobą $\mathrm{i}$ jej konsekwencjami takimi jak: ból, biegunka, złe samopoczucie $[6,7,8,9]$.

Zachowania człowieka w sytuacji choroby i ich wpływ na własne zdrowie stanowi element rozważań na temat poczucia własnej skuteczności, które jest jednym z zasadniczych mechanizmów samoregulacji ludzkich zachowań, pod względem funkcjonowania poznawczego i motywacyjnego. Wiara w swoje możliwości determinuje w jaki sposób myślimy, czujemy, zachowujemy się i jaką mamy motywację do działania. Zatem od aktywności poznawczej i sprawczej zależy przekonanie o własnej skuteczności, która oznacza wiarę we własne zdolności organizacyjne, pozwalające wdrożyć działania niezbędne do przezwyciężania napotkanych przeszkód $[10,11,12]$.

Objawy choroby, stres i radzenie sobie z nim, akceptacja choroby, poczucie własnej skuteczności i wiele innych determinantów wpływa na satysfakcję z życia człowieka [2].

Wrzodziejące zapalenie jelita grubego jest bardzo trudnym doświadczeniem dla człowieka, ponieważ znacząco zmienia styl życia, funkcjonowanie w domu, na płaszczyźnie zawodowej, czy też w kontaktach towarzyskich [13].

\section{CEL PRACY}

Celem pracy było poznanie poziomu satysfakcji z życia oraz jej wybranych determinantów takich jak: akceptacja choroby, uogólniona własna skuteczność u pacjentów $\mathrm{z}$ wrzodziejącym zapaleniem jelita grubego.

\section{MATERIAŁ I METODY}

Poziom satysfakcji z życia i jej determinanty zbadano u 102 osób z potwierdzonym rozpoznaniem klinicznym wrzodziejącego zapalenia jelita grubego, leczonych zachowawczo w Wojewódzkim Szpitalu Specjalistycznym w Częstochowie na Oddziale Gastroenterologii i w Poradni Gastrologicznej. Dobór grupy był celowy, pacjentów dobrano na podstawie potwierdzonego rozpoznania choroby oraz czasu chorowania, od co najmniej roku. Na podjęcie badań uzyskano zgodę osób chorych i Komisji Bioetycznej Okręgowej Izby Lekarskiej w Częstochowie (Nr K.B.Cz.-9/2012).

Ponad połowę badanych (52\%) stanowiły kobiety. Wiek badanych wahał się od 18 do 79 roku życia, a średnia wieku wynosiła 41,02 lat. Wykształcenie wyższe i średnie miało $85 \%$ badanych, $73 \%$ pracowało zawodowo. W badanej grupie dominowały (71\%) osoby mieszkające w mieście. Czas trwania choroby wahał się od 1 roku do 27 lat.

Do zebrania danych zastosowano metodę sondażu diagnostycznego wykorzystując standardowe narzędzia badawcze: Skalę Satysfakcji z Życia, Skalę Akceptacji Choroby, Skalę Uogólnionej Własnej Skuteczności oraz autorski kwestionariusz ankiety.

Subiektywnego poczucia zadowolenia z życia dokonano za pomocą Skali Satysfakcji z Życia (The Satisfaction with Life Scale - SWLS), która składa się z 5 stwierdzeń. W każdym pytaniu można uzyskać od 1 do 7 punktów. Wyniki podlegają zsumowaniu, a ich zakres mieści się w granicach od 5 do 35 punktów. Im wyższy wynik tym większe poczucie satysfakcji z życia [14].

Akceptację choroby oceniano Skalą Akceptacji Choroby (Acceptance of Illness Scale - AIS), która zawiera 8 stwierdzeń opisujących negatywne konsekwencje złego stanu zdrowia. W każdym stwierdzeniu badany określa swój aktualny stan w skali pięciostopniowej od 1 do 5. Wyniki podlegają zsumowaniu, a ich zakres mieści się w granicach od 8 do 40 . Niski wynik oznacza brak akceptacji i przystosowania do choroby oraz silne poczucie dyskomfortu psychicznego. Wynik wysoki świadczy o akceptacji własnego stanu chorobowego, co przejawia się brakiem negatywnych emocji związanych z chorobą [14].

Uogólnioną własną skuteczność oceniano przy użyciu Skali Uogólnionej Własnej Skuteczności (Generalized Self - Efficacy Scale - GSES), która zawiera 10 stwierdzeń i służy do oceny skuteczności radzenia sobie jednostki z trudnymi sytuacjami oraz przeszkodami. Osoba badana 
zaznacza odpowiedzi wybierając cztery warianty. Wyniki uzyskuje się sumując punkty, mieszczące się w granicach od 10 do 40 . Im wyższy wynik, tym większe poczucie własnej skuteczności [14].

Autorski kwestionariusz ankiety zawierał 12 pytań dotyczących danych socjodemograficznych, funkcjonowania zawodowego, towarzyskiego i rodzinnego osób badanych.

Do analizy danych zastosowano statystykę opisową i testy parametryczne i nieparametryczne w zależności od rodzaju skali i charakteru rozkładu zmiennych. Analizy korelacyjne dla zmiennych wyrażonych w skalach porządkowych dokonano za pomocą korelacji r-Pearsona. Wyniki przyjęto jako istotne statystycznie przy poziomie istotności $\mathrm{p}<0,05$.

\section{WYNIKI}

Analiza uzyskanych danych wykazała, że badaną grupę charakteryzuje średni poziom $(21,14)$ satysfakcji z życia, przy odchyleniu standardowym - 6,05. Na poziom satysfakcji z życia miało wpływ wykształcenie badanych. Niższy poziom satysfakcji z życia prezentowali badani z wykształceniem zawodowym, a najwyższy z wykształceniem wyższym.

Kobiety uzyskały nieznacznie niższy poziom satysfakcji z życia $(20,4)$ niż mężczyźni $(21,9)$.

Analiza statystyczna nie wykazała zależności satysfakcji z życia od wieku i czasu trwania choroby. Uzyskany w badaniu średni poziom akceptacji choroby wynosił 28,7 przy odchyleniu standardowym - 8,4 i świadczył o przeciętnej akceptacji choroby. Znaczna grupa osób badanych $74 \%$ wykazała wysoki poziomem akceptacji choroby uzyskując średnią 32,69, a niski poziom akceptacji uzyskało $26 \%$ badanych ze średnią 17,63.

Najwyższy procent badanych z najniższą akceptacją choroby występował w grupie osób z wykształceniem zawodowym, natomiast w grupie osób z wykształceniem średnim było najwięcej z wysokim poziomem akceptacji choroby.

Kobiety uzyskały nieznacznie niższy poziom akceptacji choroby $(27,2)$ niż mężczyźni $(30,3)$.

Analiza zależności poziomu akceptacji choroby badanych wykazała niewielki spadek akceptacji choroby wraz z wiekiem i wzrostem czasu trwania wrzodziejącego zapalenia jelita grubego.

Ocena uogólnionej własnej skuteczności wykazała jej średni poziom - 30,48, przy odchyleniu standardowym 5,25 . Wyniki te mogą przemawiać za obniżoną uogólnioną własną skutecznością wśród osób badanych.

Analiza uogólnionej własnej skuteczności w zależności od wykształcenia wykazała, że najwyższy procent badanych z najniższą uogólnioną własną skutecznością występował w grupie $\mathrm{z}$ wykształceniem zawodowym, natomiast najwyższy procent badanych $\mathrm{z}$ wysokim poziomem uogólnionej własnej skuteczności występował w grupie $\mathrm{z}$ wykształceniem wyższym.

Kobiety uzyskały nieznacznie niższy poziom uogólnionej własnej skuteczności $(28,9)$ niż mężczyźni $(32,2)$.
Analiza wysokiej i niskiej uogólnionej skuteczności w zależności od wieku i czasu trwania choroby wykazała, że badani z niższą średnią wieku prezentowali wysoką uogólnioną własną skuteczność. Natomiast badani z dłuższym czasem chorowania prezentowali niewielki spadek uogólnionej własnej skuteczności (Tab.1). Wykazano słabą ujemną zależność pomiędzy uogólnioną własną skutecznością a czasem trwania choroby $(\mathrm{R}=-0,20 ; \mathrm{p}=0,04)$.

Tab. 1. Poziom uogólnionej własnej skuteczności w zależności od czasu trwania choroby w badanej grupie

\begin{tabular}{|l|c|c|c|c|}
\hline $\begin{array}{c}\text { Liczba } \\
\text { badanych }\end{array}$ & $\begin{array}{c}\text { Poziom } \\
\text { uogólnionej } \\
\text { własnej } \\
\text { skuteczności }\end{array}$ & $\begin{array}{c}\text { Średnia } \\
\text { + SD poziomu } \\
\text { uogólnionej } \\
\text { własnej } \\
\text { skuteczności }\end{array}$ & $\begin{array}{c}\text { Średnia } \\
\text { wieku + SD }\end{array}$ & $\begin{array}{c}\text { Średnia czasu } \\
\text { trwania } \\
\text { choroby + SD }\end{array}$ \\
\hline 16 & Low & $21.44+2.78$ & $51.5+16.68$ & $10.62+7.49$ \\
\hline 86 & High & $32.16+3.64$ & $\begin{array}{c}39.07+ \\
13.31\end{array}$ & $6.44+5.57$ \\
\hline
\end{tabular}

SD - odchylenie standardowe

Nie wykazano zależności pomiędzy satysfakcją z życia a czasem trwania choroby. Analiza zależności akceptacji choroby a czasu trwania wrzodziejacego zapalenia jelita grubego wykazała niewielki spadek akceptacji wraz ze wzrostem czasu trwania choroby. Korelacja porządku rang Spearmana pomiędzy zmiennymi nie wykazała zależności $(\mathrm{R}=-0,18 ; \mathrm{p}=0,07)$.

Badając korelacje między zmiennymi stwierdzono wpływ akceptacji choroby w badanej grupie na: satysfakcję $\mathrm{z}$ życia $(\mathrm{R}=0,42 ; \mathrm{p}<0,001)$ i uogólnioną własną skuteczność $(\mathrm{R}=0,37 ; \mathrm{p}<0,001)$. Zaobserwowano również średnią korelację pomiędzy satysfakcją z życia a uogólnioną własną skutecznością $(\mathrm{R}=0,52 ; \mathrm{p}<0,001)$.

\section{DYSKUSJA}

Wrzodziejące zapalenie jelita grubego wywiera wpływ na każdą dziedzinę życia oraz funkcjonowanie psychospołeczne pacjentów. Analiza badanych zmiennych: satysfakcji z życia, akceptacji choroby i uogólnionej własnej skuteczności potwierdziła te wnioski.

Ważnym elementem zdrowia jest dobre samopoczucie, na które składają się: poziom satysfakcji z życia, pozytywne emocje i brak negatywnych uczuć [15]. Subiektywna ocena satysfakcji z życia jest porównaniem własnej sytuacji z ustalonymi przez siebie standardami, a w konsekwencji poczuciem zadowolenia $z$ siebie [16], im wyższa satysfakcja $\mathrm{z}$ życia tym mniejsze odczuwanie stresu i lepsza kontrola negatywnych uczuć.

Otrzymany wynik satysfakcji z życia badanych wahał się w granicach 6 stena $(21,14$ pkt.) i świadczył o jej przeciętnym poziomie. Kobiety uzyskały nieco niższy wynik (20,4 pkt.) niż mężczyźni (21,9 pkt.). Wyższy poziom satysfakcji z życia występował w grupie osób z wykształceniem wyższym, najniższy poziom satysfakcji uzyskała grupa $z$ wykształceniem zawodowym. Nie odnaleziono w piśmiennictwie badań na temat satysfakcji z życia pacjentów z wrzodziejącym zapaleniem jelita grubego. Wyniki badań własnych porównano $\mathrm{z}$ badaniami satysfakcji z życia $\mathrm{w}$ grupie chorych $\mathrm{z}$ innymi chorobami przewlekłymi. 
H.I. Siudalska i wsp. w badaniu chorych operowanych z powodu wad wrodzonych serca uzyskali wynik satysfakcji z życia w granicach 5 stena [17]. E. Kupcewicz, M. Wojtkowska w badaniu chorych z dyskopatią uzyskały wynik w granicach 6 stena [18]. Natomiast osoby $\mathrm{z}$ wytworzoną przetoką jelitową w badaniach przeprowadzanych przez D. Bazalińskiego i wsp. uzyskały wynik w granicach 4-5 stena [19], taki sam wynik uzyskała J. Glińska i wsp. 4-5 stenów [20]. W innych badaniach K. Budyń, A. Weiss, którymi objęto osoby starsze wynik satysfakcji z życia wahał się w granicach 5 stena [21], a kobiety w wieku geriatrycznym uzyskały wynik 6 stenów w badaniu V. Jachimowicz, T. Kostka [22]. W badaniach własnych uzyskano podobne wyniki satysfakcji z życia $\mathrm{w}$ porównaniu $\mathrm{z}$ badaniami innych autorów. Najniższy poziom satysfakcji z życia obserwowano w grupie osób z przetoką jelitową.

K. Czubalski, B.J. Felton i T.A. Revenson w swoich badaniach wykazali, że wyższy poziom akceptacji choroby świadczy o lepszym przystosowaniu do choroby i mniejszym dyskomforcie psychicznym chorego $[23,24]$. Inni autorzy $[25,26,27,28]$ potwierdzają powyższą tezę wskazując równocześnie na przeżywanie przez chorego mniej negatywnych emocji. Według C.A. Siegel osoby o wyższym poziomie akceptacji choroby wykazują większy optymizm, zaufanie do zespołu terapeutycznego i metod leczenia, co prowadzi do aktywnego udziału pacjenta w procesie terapeutycznym [29].

W badaniach własnych średni wynik akceptacji choroby wynosił 28,7. Kobiety uzyskały średni wynik niższy (27,2 pkt.) w porównaniu z grupą mężczyzn (30,3 pkt.). Wyższy poziom akceptacji choroby uzyskali badani z wykształceniem średnim. Uzyskanych wyników nie można odnieść do wyników innych autorów, ponieważ dotychczas nie prowadzono badań w odniesieniu do chorych z wrzodziejącym zapaleniem jelita grubego. Wyniki badań własnych porównano $\mathrm{z}$ wynikami autorów prowadzących badania w innych chorobach przewlekłych. W grupie chorych z cukrzycą średnie wyniki akceptacji uzyskane przez K. Kurowską i B. Lach wynosiły 25,16 pkt. [30], a przez K. Kurpas i wsp. 29 pkt. [31]. Natomiast A. Marzec i wsp. w grupie chorych poddawanych hemodializie uzyskali średni wynik 22,10 pkt. [32]. Pacjenci $\mathrm{z}$ chorobą Grave-Basedowa w badaniu prowadzonym przez M.A. Basińską i wsp. uzyskali średni wynik 28,48 pkt. [33]. W innym badaniu M.A. Basińska i A. Kasprzak u pacjentów chorych na łuszczycę uzyskali średni wynik akceptacji choroby 27,46 pkt. [34]. Grupa kobiet leczonych $\mathrm{z}$ powodu zmian patologicznych szyjki macicy osiągnęła średni wynik akceptacji na poziomie 28,76 pkt. w badaniu M. Kaźmierczak i wsp. [35].

Zarówno w badaniach własnych jak i zaprezentowanych, innych autorów średni wynik akceptacji choroby był porównywalny, choć nieco niższy u chorych hemodializowanych.

Poczucie własnej skuteczności zwane też samoskutecznością, to ważny wyznacznik funkcjonowania psychospołecznego człowieka odpowiadający za motywację, czyli gotowość i podejmowanie działań prozdrowotnych [36,37].

Badana grupa uzyskała średni wynik uogólnionego poczucia własnej skuteczności wynoszący 30,48 pkt.
Kobiety uzyskały wynik niższy (28,9 pkt.) niż badani mężczyźni (32,2 pkt.). Najwyższy poziom uogólnionej własnej skuteczności występował wśród chorych $\mathrm{z}$ wykształceniem wyższym (43\%), a najniższy z wykształceniem zawodowym (16\%). Chorzy z rozpoznaniem stwardnienia rozsianego uzyskali średni wynik 29,5 pkt. [38], z chorobą niedokrwienną serca po pomostowaniu aortalno-wieńcowym leczeni sanatoryjnie 30,7 pkt. [39], kobiety z rozpoznaną endometriozą uzyskały wynik 30,0 pkt. [40]. Prezentowane badania wykazały porównywalny poziom uogólnionej własnej skuteczności z wynikami własnymi.

Wykazano związek pomiędzy poczuciem uogólnionej własnej skuteczności badanych, a akceptacją choroby i satysfakcją z życia.

Dokonywanie oceny elementów składowych jakości życia pacjentów z wrzodziejącym zapaleniem jelita grubego z pewnością usprawnia komunikację w zespole terapeutycznym pozwalając objąć pacjenta holistyczną opieką, której spodziewanym efektem powinna być poprawa przebiegu leczenia oraz utrzymanie jak najdłuższego okresu remisji choroby. W praktyce najczęściej nie dokonuje się całościowej oceny jakości życia osób przewlekle chorych, a co najwyżej ogranicza się ją do kilku pytań dotyczących ich samopoczucia. Rutynowa, profesjonalna ocena jakości życia chorych ma wpływ na wybór i skuteczność postępowania, przyczynia się do zmotywowania pacjenta do samokontroli i przestrzegania zaleceń lekarskich. Biorąc to po uwagę należy podkreślić, że profesjonalna ocena stanu zdrowia pacjenta $\mathrm{z}$ chorobą przewlekłą ma ogromne znaczenie w optymalizacji zindywidualizowanej opieki.

\section{WNIOSKI}

1. Satysfakcja z życia, akceptacja choroby i uogólniona własna skuteczność u badanych pacjentów $\mathrm{z}$ wrzodziejącym zapaleniem jelita grubego były obniżone.

2. Badani z wykształceniem zawodowym osiągali niższe wyniki badanych zmiennych niż osoby z wykształceniem wyższym, czy średnim.

3. Kobiety prezentowały niższe poziomy badanych zmiennych niż mężczyźni.

4. Poziom satysfakcji z życia był zależny od poziomu akceptacji choroby i własnej skuteczności.

5. Poziom satysfakcji z życia badanych korelował z uogólnioną własną skutecznością i akceptacją choroby. Wyższy poziom satysfakcji z życia uzyskali badani z wyższym poziomem akceptacji choroby i przekonani o skutecznym radzeniu sobie $\mathrm{z}$ sytuacjami trudnymi i przeszkodami.

6. Poziom uogólnionej własnej skuteczności badanych korelował z akceptacją choroby, satysfakcją z życia i płcią. Wyższy poziom uogólnionej skuteczności uzyskali badani wyższym poziomem akceptacji choroby i osiągający lepszą satysfakcję z życia. Mężczyźni prezentowali lepsze wyniki niż kobiety. 


\section{REFERENCES/PIŚMIENNICTWO}

1. Giddens A. Nowoczesność i tożsamość. "Ja” i społeczeństwo w dobie późnej nowoczesności. Warszawa: Wydawnictwo Naukowe PWN; 2010.

2. Diener $E$, Lucas RE, Oishi $S$. Subjective well-being. The science of happiness and life satisfactions. [in:] Snyder CR, Lopez SJ. (red). Handbook of positive psychology. Oxford: Oxford University Press, 2005.

3. Pavot W, Diener E. Review of the satisfaction with Life Scale. Psych Assess. 1993; 5(2): 164-172.

4. Lucas RE. Adaptation and the Set-Point model of subjective well-beging.Does happiness change after major life events? Curr Dir in Psychol Sci. 2007; 16 (2): 75-79.

5. Dolińska-Zygmunt $\mathrm{G}$. Podmiotowe uwarunkowania zachowania się pacjenta wobec własnej choroby. [in:] Dolińska-Zygmunt G. Elementy psychologii zdrowia. Wrocław: Wydawnictwo UW; 1996, s. 195-205.

6. Krasuska ME, Turnowski K. Wybrane aspekty opieki nad pacjentem onkologicznym. Lublin: Neuro Centrum; 1996.

7. Glińska J, Hebda A, Dziki A. Impact of nursing care on the quality of life of patient with an enteric stoma. Proktologia. 2005; 6: 232-239.

8. Majkowicz M. Wybrane problem psychoonkologii z uwzględnieniem zagadnień psychiatrycznych. Psychiatr Prakt Klin. 2008; 1(2): 57-66.

9. de Gouveia Santos VL, Chaves EC, Kimura M. Quality of life and coping of persons with temporary and permanent stomas. J Wound Ostomy Continence Nurs. 2006; 33: 503-509.

10. Bandura A. Self-efficacy toward a unifying of behavioral change. Psychol Rev. 1977; 84(2): 191-215

11. Bandura A. Self-efficacy mechanism in human agency. Am Psychol. 1982; 37(2): 122147.

12. Bandura A. Social cognitive theory: an agentic perspective. Annu Rev Psychol. 2001; 52: $1-26$.

13. Jarosz M. Psychologia lekarska. Warszawa: Wydawnictwo PZWL; 1988, s. 247-266.

14. Jurczyński J. Narzędzia pomiaru w promocji i psychologii zdrowia. Warszawa: Pracownia Testów Psychologicznych Polskiego Towarzystwa Psychologicznego, PWN; 2001.

15. Diener E. Subjective well-being. Psychol Bull. 1984; 95(3): 542-575.

16. Pavot W, Diener E. Review of the satisfaction with Life Scale. Psychol Assess. 1993; 5: $164-172$.

17. Siudalska H, Różański J, Kuśmierczyk M, i wsp.: Odległa psychologiczna ocena pacjentów operowanych z powodu wad wrodzonych serca. Kardiochir Torakochir Pol. 2008; 5(4): 381-385.

18. Kupcewicz E, Wojtkowska M. Akceptacja choroby a poczucie satysfakcji z życia w grupie chorych leczonych z powodu dyskopatii. Instytut Warmińsko-Mazurski w Olsztynie; 2009.

19. Bazaliński D, Sałacińska I, Więch P, Kózka M. Life satisfaction and self-efficacy in patients with stoma. Progress in Health Science. 2014; 4(2): 22-30.

20. Glińska J, i wsp. Ocena stopnia satysfakcji z życia u osób ze stomią jelitową wzależności od wybranych czynników demograficznych. Piel Chir Angiol. 2014; 3: 128-132.

21. Mudyń K, Weiss A. Satysfakcja zżycia osób w wieku senioralnym a orientacje życiowe i deklarowane wartości. Społeczeństwo i Rodzina. 2010; 22: 1-18.

22. Jachimowicz V, Kostka T. Satysfakcja z życia starszych kobiet. Ginekol Prakt 2009; 3: 27-32.

23. Czubalski K. Medycyna psychosomatyczna - koncepcje, cele, metody. Pol Tyg Lek. 1977; 47: 1857-1860.

24. Felton BJ, Revenson TA. Coping with chronic illness: a study of illness controllability and the influence of coping strategies on psychological adjustment. J Consult Clin Psychol. 1984; 52(3): 343-353.

25. Kossakowska M.: Strategie radzenia sobie z chorobą przewlekłą w stwardnieniu rozsianym. Post Psychiatr Neurol 2008; 17: 15-21.

26. Motyka M. Psychoterapia elementarna w opiece ogólnomedycznej. Kraków: Wyd. Uniwersytetu Jagiellońskiego; 2002.

27. Karski JB. Praktyka i teoria promocji zdrowia. Wyd. II. Warszawa: Wyd. CeDeWu Sp. z 0.0., 2006.

28. Oleś $\mathrm{P}$, Steuden $\mathrm{S}$, Toczołowski J. Jak świata mniej widzę: zaburzenia widzenia a jakość życia. Lublin: Towarzystwo Naukowe Katolickiego Uniwersytetu Lubelskiego; 2002.

29. Siegel CA. Making therapeutic decisions in inflammatory bowel disease: the role of patients. Curr Opin in Gastroenterol. 2009; 25(4):334-338.

30. Kurowska K, Lach B. Akceptacja choroby i sposoby radzenia sobie ze stresem u chorych na cukrzycę typu 2. Diabetol Prakt. 2011; 12(3): 113-119.

31. Kurpas D, Czech T, Mroczek B. Akceptacja choroby pacjentów z cukrzycą oraz jej wpływ na jakość życia i subiektywną ocenę zdrowia. Fam Med Prim Care Rev. 2012; 14(3): 383-388.
32. Marzec A, Andruszkiewicz A, Banaszkiewicz M. Poczucie koherencji, akceptacja choroby a funkcjonowanie w chorobie przewlekłej osób chorych na chorobę nerek i chorych na cukrzycę, hemodializowanych - doniesienie wstępne. Pielęg XXI. 2011; 2(35): 51-56

33. Basińska MA, Zalewska-Rydzkowska D, Wolańska P, Junik R. Dyspozycyjny optymizm a akceptacja choroby w grupie osób z chorobą Gravesa-Basedowa. Endokrynol Pol. 2008; 59 (1): 23-28.

34. Basińska MA, Kasprzak A. Związek między strategiami radzenia sobie ze stresem a akceptacją choroby w grupie osób chorych na łuszczycę. Prz Dermatol. 2012; 99: 692-700.

35. Kaźmierczak M, Kubiak I, Gebuza G, i wsp. Czynniki determinujące akceptację choroby przez kobiety leczone z powodu zmian patologicznych szyjki macicy. Medycyna Ogólna i Nauki o Zdrowiu. 2015; 21(2): 181-186.

36. Bandura A. Social foundations of thought and action: A social cognitive theory. Englewood. Cliffs, NJ: Prentice-Hall; 1986.

37. Schwarzer R. Poczucie własnej samoskuteczności w podejmowaniu i kontynuacji zachowań zdrowotnych. Dotychczasowe podejście teoretyczne i nowy model. [w:] Heszen-Niejodek I, Sęk H. (red). Psychologia zdrowia. Warszawa: PWN; 1997.

38. Wrzesińska MA, Opuchlik K, Kocur J. Ocena umiejscowienia kontroli zdrowia oraz poziomu poczucia własnej skuteczności i optymizmu u chorych na stwardnienie rozsiane. Post Psychiatr Neurol. 2008; 17(4): 313-318.

39. Guzińska K, Kupc A, Borys B. Zasoby odporności na stres w procesie zdrowieniu u pacjentów z chorobą niedokrwienną serca. Via Medica, Gdańska. 2007; 4: 144-152.

40. Łuczak-Wawrzyniak J, Szczepańska M, Skrzypczak J. Ocena jakości życia kobiet z rozpoznaną endometriozą oraz sposób radzenia sobie z negatywnymi skutkami choroby. Prz Menopauz. 2007; 6: 329-335.

Manuscript received/Praca zgłoszona do czasopisma: 30.11 .2018

Manuscript accepted/Praca zaakceptowana do druku: 07.02.2019

Translation/Tłumaczenie: Irmina Czyż 